Henryk Mruk

Uniwersytet Ekonomiczny w Poznaniu

henryk.mruk@ue.poznan.pl

\title{
Uwarunkowania zarządzania własnym zdrowiem
}

Artykuł nadesłany: 8 października 2017 r.; artykuł zaakceptowany: 15 grudnia $2017 \mathrm{r}$. JEL Classification: I10, I19

Keywords: personal health, management of personal health, behavioral economics, health promotion

\section{Abstract \\ Determinants of personal health management}

The state will not be able to finance the growing needs of patients in the field of health protection. Patients will increasingly finance the use of medical services from their own income. In this situation, more than ever they will also be interested in care for their own health. Conclusions resulting from the development of behavioral economics can be helpful for patients in managing their own health. The introduction of pharmaceutical care to pharmacies in Poland can effectively help patients maintain their health and quality of life.

\section{Wprowadzenie}

Długie, udane życie, do tego w dobrym zdrowiu, to wartość niezwykle istotna dla każdego człowieka. Spoglądając na wskaźniki przeciętnej długości życia na świecie, w tym w Europie, można zaobserwować duży postęp. Dotyczy on głównie społeczeństw o wyższym stopniu rozwoju gospodarczego. Rosnące nakłady na badania i rozwój owocują powstawaniem nowych technologii medycznych, odkrywaniem nowych molekuł, które pozwalają na podnoszenie kondycji zdrowotnej ludzkości. Jednocześnie wzrasta zanieczyszczenie środowiska, nasila się terroryzm, następują procesy starzenia się społeczeństw, intensyfikowane są działania reklamujące żywność, a to tworzy zagrożenia dotyczące stanu zdrowia ludzi. Rozwijające się systemy ubezpieczeń zdrowotnych i lecznictwa mogą natrafić na barierę wydolności, jeśli pojawiające się zagrożenia przewyższą istniejące 
możliwości. Rozwój państwa jako organizatora życia społecznego osłabia świadomość pojedynczych osób w zakresie odpowiedzialności za własne zdrowie. Są oni nieświadomie przekonani, że system o nich skutecznie zadba, jeśli pojawią się kłopoty ze zdrowiem. Wysoka dostępność leków tworzy przekonania, że wystarczy sięgnąć po reklamowane preparaty, aby funkcjonować w dobrej kondycji fizycznej oraz psychicznej. Tymczasem tak nie jest. Wiele zależy od każdego człowieka - jego nawyków, troski o siebie, odpowiedzialnego odżywiania się i aktywności ruchowej.

Celem rozważań jest krytyczna analiza czynników, które wpływają na zdrowie ludzi. Najwięcej uwagi zostanie skierowane na indywidualną odpowiedzialność człowieka za własne zdrowie. Rozważania będą prowadzone w oparciu o literaturę przedmiotu, publikowane wyniki badań, obserwacje oraz rozmowy przeprowadzone z podmiotami zarządzającymi placówkami medycznymi. Metodyka rozważań odwołuje się do wnioskowania logicznego, analizy krytycznej, obserwacji jakościowych oraz metod porównawczych.

\section{Zagrożenia związane z otoczeniem}

Klasyczna metoda analizy otoczenia wiąże się z modelem PEST, obejmującym obszar czynników polityczno-prawnych, ekonomiczno-demograficznych, społeczno-kulturowych oraz technologicznych i naturalnych. W krótkim okresie trzeba brać pod uwagę zmiany prawne, często związane z polityką. W 2017 roku wprowadzono w Polsce nowe prawo dotyczące funkcjonowania aptek oraz sieci szpitali. Są to zmiany, które kształtują warunki funkcjonowania całego sektora zdrowia. Trudno jednak się spodziewać, aby wybory wygrało ugrupowanie polityczne, które zaproponuje wzrost składek na ubezpieczenia zdrowotne, wzrost podatków czy rozszerzenie wolnego rynku w sferze zdrowia. Niewielkie są zatem szanse na to, aby znacząco zwiększyły się fundusze na opiekę zdrowotną nad pacjentami. Nie można więc przyjmować nierealnych założeń, że wzrosną fundusze w systemie ochrony zdrowia. Można jedynie wprowadzać innowacje związane ze zwiększaniem stopnia efektywności ich wykorzystania. Nie będą to jednak zmiany, które pozwolą na istotne zwiększenie środków na finansowanie zdrowia ludności w formie świadczeń publicznych.

Rynek, nawet regulowany, obejmuje trzy elementy: podaż, popyt, cenę ${ }^{1}$. O stabilizacji świadczeń po stronie podaży już wspominaliśmy. Inaczej rzeczy mają się po stronie popytu. W XXI wieku w Polsce, a także w krajach Unii Europejskiej, zachodzą procesy starzenia się ludności. W dość szybkim tempie wzrasta odsetek ludności w wieku nieprodukcyjnym. Zwiększa się tym samym liczba seniorów (emerytów), którzy w ograniczonym zakresie płacą składki na ubezpieczenia zdrowotne. Zmniejsza się liczba osób, które pracują, a tym samym zasilają

1 W. Wrzosek, Funkcjonowanie rynku, Warszawa 1998. 
fundusze ubezpieczeń zdrowotnych. Przywrócenie w Polsce granic wieku przechodzenia na emeryturę (60 lat dla kobiet i 65 lat dla mężczyzn zamiast 67 lat dla wszystkich) również jest czynnikiem ograniczającym wysokość środków wpływających do funduszu ubezpieczeń zdrowotnych. Zapotrzebowanie na świadczenia zdrowotne społeczeństwa starzejącego się jest wyższe, co jest zrozumiałe. Oznacza to, że trzeba spodziewać się zwiększającej się luki między wzrostem popytu na świadczenia zdrowotne a możliwościami jego zaspokojenia. Nie ulega wątpliwości, że państwa, rządy, będą się wycofywały z ponoszenia pełnej odpowiedzialności za zdrowie społeczeństwa ${ }^{2}$. W zależności od wprowadzanych ograniczeń może to oznaczać wydłużanie się kolejek do lekarzy, trudniejszy dostęp do placówek służby zdrowia, ograniczanie koszyka świadczeń gwarantowanych itp.

Jednocześnie społeczeństwa są przekonane, że państwo powinno im zapewnić bezpłatne świadczenia medyczne. Jest to często zapisane w Konstytucji. Globalizacja powoduje, że pacjenci oczekują, iż opieka medyczna będzie na takim samym, wysokim poziomie w każdym kraju, w którym będą z niej korzystali. To również nie jest takie proste $\mathrm{z}$ uwagi na zróżnicowanie wysokości dochodu narodowego w skali Europy i świata. Wysokie nakłady na badania i rozwój owocują nowymi technologiami medycznymi, które ułatwiają powrót do zdrowia, jednakże są kosztowne i wymagają wysokich nakładów. To stoi w sprzeczności z ograniczonym poziomem funduszy na ubezpieczenia zdrowotne. Trzeba także wspomnieć o środowisku naturalnym, które jest coraz bardziej zanieczyszczone. To z kolei przekłada się na rozwijanie się chorób, które wymagają leczenia.

Poza wymienionymi, mającymi największe znaczenie dla sprawnego funkcjonowania systemu zdrowia $\mathrm{w}$ dotychczasowej postaci, istnieje wiele innych czynników. Wszystko to razem powoduje, że konieczne będzie wprowadzanie wielu zmian w istniejącym modelu sfery zdrowia. Społeczeństwa stają przed koniecznością bardziej świadomego, racjonalnego spojrzenia na zarządzanie własnym zdrowiem. Ludzie nie mogą już liczyć na to, że państwo będzie w stanie pokrywać wszystkie wydatki związane z leczeniem.

\section{Szanse związane $\mathrm{z}$ otoczeniem}

W sferze ekonomiczno-społecznej jest podobnie jak w naturze - na zagrożeniach wyrastają szanse dla nowych rozwiązań. Stare drzewo, które przewróci się w puszczy, daje możliwość dotarcia promieniom słońca, kroplom deszczu i w tym miejscu pojawiają się nowe organizmy. Podobnie jest w sferze ochrony zdrowia. Niezależnie od sektora publicznego pojawiają się prywatne placówki medyczne. Interesującym przykładem w Polsce jest stomatologia. Od chwili zreformowania całego systemu w 1989 roku zwiększała się liczba pacjentów, którzy płacą z włas-

${ }^{2}$ G. Pacenti, P. Mancini, Marketing produktów farmaceutycznych. Nowe strategie dla sektora ochrony zdrowia, Warszawa 2015. 
nych środków za usługi stomatologiczne. Wydatki na prywatną (niepubliczną) służbę zdrowia w Polsce rosły w latach 2016-2017 w tempie ponad dwukrotnie wyższym niż PKB. O ile wzrost PKB wynosi około 3,2\% rocznie, to nakłady na infrastrukturę w niepublicznym sektorze zdrowia wzrosły o około $7 \%$.

W celu ochrony własnego zdrowia coraz więcej osób decyduje się na korzystanie z usług w sektorze niepublicznym. Powstają na świecie także towarzystwa ubezpieczeniowe, które oferują dostęp do lekarzy nawet siedem dni w tygodniu $i$ dwadzieścia cztery godziny na dobę 3 . Powoduje to, że w coraz szerszym zakresie normy społeczne są wypierane przez normy rynkowe. Osoby, które dysponują odpowiednimi dochodami, mogą ominąc kolejki, korzystając z placówek prywatnych oraz wykupując prywatne ubezpieczenia. W ten sposób zwiększają się dysproporcje między ludźmi w zakresie świadczeń zdrowotnych. Dochodzi nawet do tego, że tworzy się rynek handlu ubezpieczeniami życiowymi. Osoba, która jest na przykład chora na AIDS i wie, że umrze za pół roku, może sprzedać swoją polisę wartą $1 \mathrm{mln}$ dolarów za 250 tys. dolarów. Przez pół roku spełnia wszystkie swoje zachcianki, natomiast inwestor otrzymuje bardzo wysoki zwrot pieniędzy (niekiedy kilkaset procent). Wzrost zróżnicowania dochodów powoduje, że będzie wzrastała liczba osób, które będą pacjentami prywatnej służby zdrowia. W Polsce corocznie wzrasta liczba osób, których dochody pozwalają na zwiększanie wydatków na zakupy dóbr luksusowych ${ }^{4}$. Jest to również segment, który będzie mógł korzystać z prywatnych ubezpieczeń w zakresie zdrowia oraz nabywania usług medycznych poza systemem publicznym.

Niezwykła szansa pojawia się także przed aptekami. Kolejki w aptekach albo nie istnieją, albo są bez porównania krótsze niż do lekarzy. Apteki są ponadto placówkami zlokalizowanymi po sąsiedzku w stosunku do miejsca zamieszkania pacjentów. W starzejącym się społeczeństwie możliwość otrzymania porady w aptece jest dla pacjenta istotną wartością. Zmiana prawa aptecznego oraz doskonalenie kwalifikacji farmaceutów w zakresie opieki farmaceutycznej stwarzają szanse na zwiększanie roli aptek w sferze ochrony zdrowia pacjentów.

Podobne szanse pojawiają się na rynku różnorodnych usług, w tym edukacyjnych. To tego typu placówki mogą wspierać pacjentów w zarządzaniu własnym zdrowiem. Nie są to zagadnienia proste, albowiem trudno się zmienia przekonanie ludzi o ich wyjątkowej odporności na zagrożenia czy choroby5. Skupianie się na perspektywie krótkookresowej jest dominujące ${ }^{6}$. Zarządzanie własnym zdrowiem wymaga zmiany modelu mentalnego — postrzegania swojego zdrowia fizycznego i psychicznego w perspektywie długofalowej — od młodości do późnej starości. Konstrukcja mózgu ogranicza wystąpienie takiej perspektywy mentalnej.

${ }^{3}$ M. Sandel, Czego nie można kupić za pieniadze. Moralne granice rynku, Warszawa 2013.

${ }^{4}$ P. Kwiatkowski, Doświadczenia z najwyższej pótki, „Harvard Business Review Polska”, lipiec-sierpień 2017, nr 173-174, s. R1-R12.

5 L. Mlodinow, Nieświadomy mózg, Warszawa 2017.

6 D. Ariely, Potęga irracjonalności, Wrocław 2009. 


\section{Psychologia pacjenta — ograniczenia i możliwości}

Homo sapiens ma umiejętności — ale też potrzeby — funkcjonowania pojedynczo oraz działania w grupie ${ }^{7}$. Odwoływaliśmy się dotąd do systemów ubezpieczeń społecznych czy zdrowotnych. Chociaż nie przychodzi to łatwo, to jednak ludzie rozumieją, że warto solidarnie wpłacać pieniądze na wspólny fundusz, aby możliwe było pomaganie jednostkom, które znajdą się w potrzebie. Składając się na wspólny fundusz, nikt jednak nie ma pełnej świadomości, jakie jest zapotrzebowanie na pokrywanie świadczeń medycznych. $Z$ dotychczasowych rozważań płynie wniosek, że będzie coraz większe rozwarcie między potrzebami zdrowotnymi a możliwościami ich finansowania.

Dobrobyt, w którym żyje wiele narodów na początku XXI wieku, ugruntował społeczności w przekonaniu, że państwo roztacza opiekę nad obywatelem w coraz szerszym zakresie. Ograniczyło to świadomość, że każdy człowiek ponosi odpowiedzialność za siebie, w tym za stan własnego zdrowia. Właściwa dieta, sposób odżywiania się, higiena życia (sen, wypoczynek) mogą opóźnić wystąpienie danej choroby nawet o 25 lat $^{8}$.

$\mathrm{W}$ opisanych warunkach istotne dla pacjentów będzie to, aby potrafili we właściwy sposób zarządzać swoim zdrowiem. Wymaga to zarówno wiedzy, jak i tworzenia wielu nawyków związanych ze stylem życia. Większość ludzi potrafi wytrwać jeden tydzień w postanowieniach (przykładem mogą być postanowienia noworoczne). Badania wskazują, że tylko $8 \%$ ludzi jest zdolne wprowadzić trwałe zmiany w swoim życiu9. Gdyby ten odsetek dało się zwiększyć o 1 punkt w okresie 10 lat, wówczas łatwiej przychodziłoby równoważenie podaży i popytu w zakresie usług medycznych.

Są to niezwykle złożone problemy, wymagające kształtowania odpowiednich modeli mentalnych u ludzi ${ }^{10}$. Cecha związana $\mathrm{z}$ koncentrowaniem się na chwili bieżącej jest barierą w zakresie skutecznego zarządzania posiadanymi środkami pieniężnymi. Niewielki odsetek osób ma zdolność tworzenia tak zwanych kont mentalnych ${ }^{11}$. Koncepcja ta mówi o tym, aby otrzymane w danym czasie (na przykład miesiącu) pieniądze podzielić na właściwe grupy (konta), czyli jedzenie, ubiór, wakacje, emerytura, zdrowie. W większości wypadków otrzymywane pieniądze są bowiem wydawane przede wszystkim na potrzeby bieżące.

Ludzie mają także ograniczone zdolności budowania planów i ich realizowa-

nia. Żyją raczej z dnia na dzień, nie widząc zmian, którym będą sami podlegać. Charakterystyczną cechą ludzką jest prokrastynacja, czyli odkładanie tego, co

${ }^{7}$ M. Bond, Siła innych, Warszawa 2015.

8 D. Amen, Wspieraj swój mózg —odmładzaj się, Poznań 2013.

9 R. Ohme, Emo Sapiens. Harmonia emocji i rozumu, Wrocław 2017.

10 J. Haidt, Prawy umyst, Sopot 2014.

11 R. Thaler, C. Sunstein, Impuls. Jak podejmować właściwe decyzje dotyczace zdrowia, dobrobytu i szczęścia, Poznań 2012. 
ważne, na później. Ktoś, kto czuje się dobrze, ma znacznie mniejszą motywację do przestrzegania diety czy prowadzenia higienicznego trybu życia. Zachowania ludzi w znacznie większym stopniu następują pod wpływem czynników emocjonalnych, a nie racjonalnych ${ }^{12}$. Rozwój technologii sprzyja utrwalaniu się wygody. Piloty, aplikacje czy samochody zmniejszają możliwości aktywnego krzątania się po mieszkaniu, poruszania się w biurze. Codzienny ruch, ćwiczenia uprawiane systematycznie przyniosą o wiele więcej korzyści niż wyjazd do centrum fitness na dwa tygodnie raz w roku.

Szybkie tempo życia sprzyja podejmowaniu decyzji na zasadzie myślenia szybkiego. Tymczasem skuteczne zarządzanie własnym zdrowiem wymaga myślenia wolnego ${ }^{13}$. Mózg lubi oszczędzać energię i unika wysiłku, jakim jest planowanie życia, uwzględniające różne aspekty wpływające na stan zdrowia. Ludziom trudno jest rozumieć zależności przyczynowo-skutkowe w odniesieniu do własnego zdrowia. Przykładowo: nie ulega wątpliwości, że palenie wywołuje wiele negatywnych skutków w odniesieniu do zdrowia ludzi; pochłania także dużą część środków z budżetu sfery zdrowia. Nadal jednak, szczególnie w krajach rozwijających się, odsetek ludzi palących, w tym lekarzy, utrzymuje się na wysokim poziomie. Stosowanie badań profilaktycznych jest trudnym nawykiem do wprowadzenia. Także w odniesieniu do zdrowia ludzie stosują wspomnianą prokrastynację, czyli odkładanie rzeczy ważnych na później („zacznę ćwiczyć od jutra”).

Niektóre reklamy osłabiają racjonalność spojrzenia pacjentów na swoje zdrowie. Trudno zrezygnować z kolejnej porcji pieczeni z grilla, jeśli reklama sugeruje prosty sposób na wspomaganie pracy wątroby — określona tabletka przed jedzeniem. Wykorzystanie wizerunku lekarzy czy farmaceutów w komunikowaniu się z pacjentami zagłusza instynkt kierowania się zdrowym rozsądkiem. Pacjenci w znacznie większym zakresie ufają innym osobom, a nie sobie. Nikt natomiast nie zna tak dobrze własnego organizmu jak dana osoba. Nie powinno się więc bezkrytycznie spoglądać na pojawiające się komunikaty lub rady. W przypadku zmiany w stanie własnego zdrowia konieczne jest większe zaangażowanie na rzecz zdobywania wiedzy, poszukiwania informacji, korzystania z wielu źródeł.

Jim Collins opisuje przypadek lidera dużej korporacji, który osobiście zaangażował się w czytanie artykułów naukowych na temat przypadku związanego z własnym zdrowiem ${ }^{14}$. Prowadząc przedsiębiorstwo, wykorzystywał czas po pracy, aby gromadzić informacje, studiować je i aktywnie współpracować z lekarzami w zakresie powrotu do zdrowia.

W ramach własnego zaangażowania oraz krytycznego myślenia trzeba pamiętać o tym, że pozytywne myślenie jest tylko jednym z elementów skutecznego zarządzania własnym zdrowiem. Krytycznie należy jednak podchodzić do

\footnotetext{
12 A. Kisielewicz, Logika i argumentacja, Warszawa 2017.

13 D. Kahneman, Pułapki myślenia. O myśleniu szybkim i wolnym, Poznań 2012.

14 J. Collins, M. Hansen, Wielcy z wyboru, Warszawa 2013.
} 
zaleceń, że wystarczy myśleć pozytywnie, a wszystko potoczy się właściwie. Nie jest to myślenie poprawne. Bez właściwej diety, ruchu, higieny życia nie będzie dobrego zdrowia opartego na myśleniu pozytywnym.

\section{Promowanie zdrowia versus promowanie chorób}

W czasie zajęć na pierwszym roku studiów medycznych, kiedy omawiane są różne choroby, wielu studentów rozpoznaje u siebie rozmaite objawy. Osoba, która w domu ogląda programy o przemocy na ulicach, nie będzie chciała wyjść na zewnątrz, obawiając się napaści. Hipokratesowi przypisuje się powiedzenie: „niech twoje pożywienie będzie dla ciebie lekarstwem”. Być może należałoby to przenieść do sfery promocji, komunikowania się. Reklamy mówiące o chorobach, reportaże, artykuły i różnorodne nieszczęścia wpływają na sposób myślenia i postrzegania świata. Tymczasem akcentowanie zdrowia, zaangażowania, aktywności może zmieniać zachowania ludzi oraz zwiększać efektywność funkcjonowania placówek medycznych. Zmiana paradygmatu w zarządzaniu organizacjami medycznymi może w istotny sposób zwiększać efektywność wydatków ${ }^{15}$.

Przykładem może być holenderska organizacja Buurtzorg skupiająca pielęgniarki. Zmieniła ona bowiem zasady działania. Typowa, hierarchiczna korporacja została zastąpiona strukturą opartą na kręgu, na zespołach. Ta struktura, nosząca nazwę holokracji lub organizacji turkusowych, postawiła na budowanie relacji w kontaktach pielęgniarek z pacjentami. Okazało się, że wielu z nich, przykutych dotąd do łóżka, zaczęło w coraz większym stopniu być aktywnymi, zajmować się sobą, być bardziej samodzielnymi. Ponadto pielęgniarki włączyły rodziny do współpracy z pacjentami. W efekcie uzyskano do $40 \%$ wzrostu efektywności działania. To jeden z przykładów, jak można zwiększać skuteczność i efektywność działania systemu opieki zdrowotnej.

Zmiana paradygmatu podejścia, czyli promowania zdrowia zamiast informacji o chorobach, jest trudna z uwagi na brak możliwości sprawdzenia alternatywy. Kiedy finansuje się świadczenia medyczne, wszystko wydaje się logiczne i uzasadnione. Przeznaczanie pieniędzy na działania profilaktyczne, na promowanie zdrowia jest trudniejsze do uzasadnienia z uwagi na to, że nie ma łatwych sposobów zmierzenia efektywności tych wydatków. Kiedy ktoś złamie nogę i zostanie poddany leczeniu, jest konkretny efekt w postaci powrotu do zdrowia. Jeśli natomiast chodniki są posprzątane i nikt nie złamie kończyny, to nie wiadomo, jak zmierzyć efektywność poniesionych nakładów. Stosownie do wspomnianej działalności człowieka, czyli pojedynczej osoby oraz grupy, można rozważać kwestie działań nastawionych na społeczeństwo (akcja szczepienia się) oraz na aktywność pojedynczych osób (właściwe odżywianie się, ruch). Z punktu widzenia efektywności całej sfery zdrowia warto promować wszystko, co wiąże się z działaniami

15 F. Laloux, Pracować inaczej, Warszawa 2016. 
o charakterze równoległym. Mamy tutaj na myśli doświadczenia innych kultur (medycyna chińska), niszowe specjalności (osteopatia) czy medycynę dietetyczną. Od początku XXI wieku wzrosło w Polsce zainteresowanie bieganiem, co należy ocenić jako promowanie zdrowego trybu życia.

W promowaniu zdrowia można stawiać na uruchamianie różnorodnych inicjatyw lokalnych. W tym wypadku duże znaczenie mogą mieć rozmaite organizacje oraz liderzy lokalni. Pojedyncza osoba może bowiem uczynić wiele dobrego dla danej społeczności, jeśli zorganizuje odpowiedni system edukacji oraz aktywności ${ }^{16}$. Zaznaczoną $\mathrm{w}$ tytule tego punktu zmianę w podejściu do promowania zdrowia można zilustrować działaniami promocyjnymi producenta samochodów. Otóż tradycyjne hasło „,sprzedajemy samochody” zmieniono na ,pomagamy klientom kupować samochody"17. Nie jest to proste, jednak wskazuje na możliwość innego podejścia do działań komunikacyjnych.

Innym, oryginalnym podejściem jest unikatowe zdanie: „piątkowa balanga czerpie z energii soboty" ${ }^{18}$. Nawiązuje ono również do filozofii umiaru, harmonii w codziennym funkcjonowaniu pacjentów.

Propagowanie tego typu idei służy ludziom. Także w szkołach, od pierwszych klas, warto postawić na kształtowanie nawyków związanych z promowaniem zdrowia.

\section{Opieka farmaceutyczna wsparciem dla pacjenta}

Wspominaliśmy już, że apteka jako placówka z sąsiedztwa będzie służyła w większym niż dotąd zakresie opiece nad zdrowiem pacjentów. Wprowadzone w 2017 roku zmiany w prawie farmaceutycznym mogą być wsparciem dla wprowadzania opieki farmaceutycznej w tego typu placówkach. Jest to kwestia złożona, obejmująca wiele różnorodnych aspektów, niemniej jednak istotna dla wdrożenia w całym systemie zdrowia ${ }^{19}$. Nie ulega wątpliwości, że podstawowe znaczenie mają uregulowania prawne, umożliwiające wprowadzenie opieki farmaceutycznej do aptek. Poza nimi ważne jest przygotowywanie placówek oraz farmaceutów do świadczenia opieki farmaceutycznej. Wobec kolejek do lekarzy coraz więcej pacjentów będzie poszukiwało pomocy w aptekach, u farmaceutów. Właściwym rozwiązaniem może być wydzielenie w aptece miejsca, gdzie będzie możliwa bezpośrednia, dyskretna, bezpieczna rozmowa pacjenta z farmaceutą. Nie ulega wątpliwości, że wymaga to odpowiednich nakładów na dostosowanie apteki do świadczenia doradztwa. Rozmowa z pacjentem na temat jego zdrowia wymaga także odpo-

16 S. Gawłowski, H. Mruk, Przywództwo. Teoria i praktyka, Poznań 2017.

17 D. Scott, Nie przeszkadzaj klientowi w zakupach, Warszawa 2015.

18 M. Brzeziński, Głaskologia. Faktyczne reguły motywowania i rozumienia motywacji, Warszawa 2013.

19 K. Szalonka, Opieka farmaceutyczna w ochronie zdrowia Polaków, Warszawa 2011. 
wiednich kwalifikacji farmaceutów. Nie chodzi tutaj o wiedzę merytoryczną, którą farmaceuci posiadają. Mamy tutaj na myśli umiejętności komunikowania się z pacjentami, znajomość technik perswazji czy argumentacji. Są to umiejętności inne niż te, które będą wymagane w pracy za pierwszym stołem. Nie każdy farmaceuta posiada kompetencje do świadczenia opieki farmaceutycznej. Nie ma też odpowiedniej świadomości w społeczeństwie, jakoby farmaceuta z własnej inicjatywy miał zadawać pacjentowi pytania odnośnie do jego zdrowia. Trudno w Polsce zaakceptować taką sytuację. Otóż farmaceuta, który zaobserwuje, że jego pacjent zaczyna przybierać na wadze, poprosi go o rozmowę. I w tej rozmowie powie wprost, że pacjent ma nadwagę, że powinien się tym zająć. Takie zachowanie nie będzie łatwe do zaakceptowania przez pacjentów, chociaż byłoby wysoce pożądane. Ludzie wolą bowiem akceptować tak zwane białe kłamstwa (,nie jesteś za gruby, dobrze wyglądasz").

W sytuacji, w której nie są refundowane koszty świadczenia opieki farmaceutycznej w aptekach, będą one zmuszone do podejmowania działań, które zapewnią odpowiednią rentowność. Trzeba też zdawać sobie sprawę, że rządy i ubezpieczyciele będą dążyć do obniżania marż aptecznych. Wzrost liczby leków generycznych również wpływa na obniżenie obrotów i marż aptecznych. Wobec takich ograniczeń warte rozważenia będzie poszerzenie asortymentu aptecznego o kosmetyki, suplementy diety, a także inne produkty. Z kolei szeroki asortyment wymaga większej powierzchni handlowej, a może nawet samoobsługi. Szeroka oferta stwarza konieczność poszerzania kwalifikacji farmaceutów w zakresie obsługi pacjentów. Prowadzi to do pojawienia się dysonansu poznawczego. Farmaceuci, obok realizacji misji zawodu, będą musieli sobie radzić także z obsługiwaniem pacjentów w sferze coraz szerszego asortymentu. Jednakże realizowanie misji zawodu, świadczenia opieki farmaceutycznej, będzie wymagało od aptek pozyskiwania marży z tytułu sprzedawania większej liczby produktów.

\section{Zarządzanie własnym zdrowiem z perspektywy ekonomii behawioralnej}

Nauki ekonomiczne od początku istnienia bazowały na paradygmacie homo oeconomicus, czyli założeniu o racjonalności zachowań konsumentów. Pod koniec $\mathrm{XX}$ wieku coraz powszechniejsza stawała się teza o znacznie większym wpływie emocji na decyzje konsumentów ${ }^{20}$. Rozwój badań nad funkcjonowaniem ludzkiego mózgu wskazuje na ograniczony wpływ czynników racjonalnych w podejmowanych decyzjach. Dotyczy to także sfery zdrowia. Mając coraz większą wiedzę na temat rzeczywistych, a nie deklarowanych zachowań pacjentów można ich wspierać w skutecznym zarządzaniu własnym zdrowiem.

20 A. Damasio, Bład Kartezjusza. Emocje, rozum i ludzki mózg, Poznań 1999. 
Odwołamy się tutaj do różnych praktycznych rozwiązań stosowanych w poszczególnych krajach, które wykorzystują wiedzę z obszaru ekonomii behawioralnej. W USA, gdzie obserwuje się nadwagę wśród dzieci, zaprojektowano eksperyment w stołówkach szkolnych. Otóż na wysokości oczu, czyli od 130 do $170 \mathrm{~cm}$ od podłogi, umieszczono dania zdrowe (warzywa, owoce, białe mięso, kompoty). Wyżej oraz niżej były frytki, hamburgery, coca-cola, chipsy itp. Po kilku miesiącach trwania eksperymentu okazało się, że zmniejszyła się skala nadwagi dzieci21. Takich efektów nie przyniosłoby jednak zachęcanie dzieci do zmiany nawyków żywieniowych. Natomiast znając mechanizmy decyzyjne (wybór z wysokości oczu), można wpływać na decyzje dzieci. Ludziom zależy na tym, aby mieli wybór. I to właśnie zagwarantowano w tym eksperymencie. Wszystko było dostępne, jednak wiedza o mechanizmach decyzyjnych pomogła w skutecznym zarządzaniu własnym zdrowiem.

Wydrukowanie i rozdanie pacjentom mapek z zaznaczonymi punktami szczepień okazuje się bardziej skuteczne niż wyłożenie ulotek zachęcających do zaszczepienia się 22 . Warte rozważenia jest także stosowanie bodźców ekonomicznych. Wypłacanie premii za witalność przez ubezpieczyciela (udział w programach zdrowotnych) powoduje zmiany trybu życia. Współpłacenie za leczenie przez pacjenta, który nie ma badań profilaktycznych, również wpływa na zmianę zachowań pacjentów. Ludzie łatwiej reagują na bodźce, zwłaszcza ekonomiczne, niż na apele i reklamę społeczną. W niektórych krajach ustanowiono zatem prawo, że kierowca, który uczestniczy w wypadku, a nie ma opon zimowych, nie otrzymuje ubezpieczenia. Spowodowało to istotną zmianę zachowań - zakładali opony zimowe.

Coraz większe nadzieje można pokładać w korzystaniu z nowych technologii w odniesieniu do zarządzania własnym zdrowiem. Kilka przykładów może zachęcać do wprowadzania nowych rozwiązań. Rehabilitant, który nagra ćwiczenia z pacjentem i udostępni je mu w sieci, ułatwi ich samodzielne wykonywanie w domu. Po wyjściu z placówki pacjenci nie zapamiętują bowiem wielu rzeczy. Prowadzenie bloga przez lekarza pozwala pacjentom na zdobywanie wiedzy oraz korygowanie własnych zachowań. Nawet aplikacje dostępne w telefonach komórkowych mogą ułatwiać pacjentom zarządzanie zdrowiem. Dla wielu z nich media społecznościowe są narzędziem, które może wspierać zdrowie.

\section{Podsumowanie}

Całościowe, harmonijne spojrzenie na własne zdrowie można porównać z żonglowaniem piłeczkami. Otóż wykwalifikowany żongler może kontrolować nawet pięć piłeczek, podrzucając i bez problemu łapiąc je w dłonie. Owe pięć piłeczek można

${ }^{21}$ R. Thaler, C. Sunstein, Impuls. Jak podejmować właściwe decyzje dotyczace zdrowia, dobrobytu i szczęścia, Poznań 2012.

22 R. Dooley, Neuromarketing, Warszawa 2016.

Ekonomia — Wroclaw Economic Review 23/4 (2017)

(C) for this edition by CNS 
odnieść do obszarów życia człowieka, czyli (1) pracy zawodowej, (2) rozwoju osobistego, (3) życia rodzinnego, (4) relacji towarzyskich i (5) społecznych. W kwestii pracy zawodowej trzeba pamiętać, aby nie prowadziła ona do wypalenia zawodowego. Kluczowe znaczenie ma rozwój osobisty. Tutaj warto opracować i wdrażać plan właściwego odżywiania się, odpowiednio długi sen, codzienną aktywność fizyczną, ale też rozwój intelektualny oraz duchowy. Wspomniana działalność człowieka wskazuje na konieczność budowania oraz pielęgnowania rodziny, podtrzymywania relacji towarzyskich, a także aktywności w ramach społeczności lokalnych czy zawodowych. Trzeba również zachować dystans do działań, które są zauważane w społeczeństwie, natomiast nie mają wpływu na zmianę zachowań pacjentów. Przykładem może być zmiana opakowań papierosów. Wydrukowanie zdjęć z obrazami skutków palenia (rak gardła, płuc), zajmujących niemal całą powierzchnię opakowania, nie wpływa na zmniejszenie liczby osób palących papie$\operatorname{rosy}^{23}$. Z pozoru może się wydawać, że będą to działania skuteczne, wpływające na pozbywanie się nałogów. Jednak wiedza na temat rzeczywistych zachowań konsumentów zaprzecza istnieniu takiej zależności. Rozwój badań w sferze ekonomii behawioralnej może skutkować doskonaleniem sposobów wpływania na wyższą skuteczność zarządzania własnym zdrowiem przez społeczeństwo.

\section{Bibliografia}

Amen D., Wspieraj swój mózg —odmładzaj się, Poznań 2013.

Ariely D., Potęga irracjonalności, Wrocław 2009.

Bond M., Sita innych, Warszawa 2015.

Brzeziński M., Głaskologia. Faktyczne reguły motywowania i rozumienia motywacji, Warszawa 2013.

Collins J., Hansen M., Wielcy z wyboru, Warszawa 2013.

Damasio A., Błąd Kartezjusza. Emocje, rozum i ludzki mózg, Poznań 1999.

Dooley R., Neuromarketing, Warszawa 2016.

Gawłowski S., Mruk H., Przywództwo. Teoria i praktyka, Poznań 2017.

Haidt J., Prawy umyst, Sopot 2014.

Kahneman D., Pułapki myślenia. O myśleniu szybkim i wolnym, Poznań 2012.

Kisielewicz A., Logika i argumentacja, Warszawa 2017.

Kwiatkowski P., Doświadczenia z najwyższej półki, „Harvard Business Review Polska”, lipiecsierpień 2017, nr 173-174.

Laloux F., Pracować inaczej, Warszawa 2016.

Lindstrom M., Zakupologia, Kraków 2009.

Mlodinow L., Nieświadomy mózg, Warszawa 2017.

Ohme R., Emo Sapiens. Harmonia emocji i rozumu, Wrocław 2017.

Pacenti G., Mancini P., Marketing produktów farmaceutycznych. Nowe strategie dla sektora ochrony zdrowia, Warszawa 2015.

Sandel M., Czego nie można kupić za pieniądze. Moralne granice rynku, Warszawa 2013.

Scott D., Nie przeszkadzaj klientowi w zakupach, Warszawa 2015.

23 M. Lindstrom, Zakupologia, Kraków 2009.

Ekonomia — Wroclaw Economic Review 23/4 (2017)

(C) for this edition by CNS 
Szalonka K., Opieka farmaceutyczna w ochronie zdrowia Polaków, Warszawa 2011.

Thaler J., Sunstein C., Impuls. Jak podejmować właściwe decyzje dotyczace zdrowia, dobrobytu i szczęścia, Poznań 2012.

Wrzosek W., Funkcjonowanie rynku, Warszawa 1998. 